\title{
Electronic Banking and Financial Performance of Commercial Banks in Kenya
}

\author{
Mutisya Maria Mueni' ${ }^{1}$, Gerald Atheru ${ }^{2}$ \\ ${ }^{1}$ Correspondent Author, Kenyatta University, Kenya \\ ${ }^{2}$ Department of Accounting and Finance, Kenyatta University, Kenya
}

\section{ABSTRACT}

Information technology has changed the traditional ways of doing business to a digital and electronic way that has led to globalization. The banking industry has been forced by the wave of electronic payment system in the business environment to change from its traditional ways such as: long queues as customers waited to be served, delay in the clearing house as representatives of different banks waited to settle their dues and manual work that resulted to errors. The main purpose of the study was to determine the effect of electronic banking on the financial performance of commercial banks in Kenya. The specific objectives were to determine the extent of internet, mobile, automated teller machine and debit/credit card banking adoption and its effect on financial performance. The study covered a period of five years that is from the year 2011 to the year 2015 and adopted descriptive research design. The data collected was analyzed by the use of both descriptive and inferential statistics procedures. Primary and secondary data was collected from the 34 commercial banks that responded leading to a respond rate of $79.04 \%$ out of the 43 commercial banks. The trade analysis showed that internet banking was recognized and accepted by the Kenyan commercial banks and the Kenyans as a way of transacting. Electronic banking was found to be positive and significantly related to the financial performance of the commercial banks in Kenya. This was attributed by an $R$ Square of 0.688 for Return On Assets, 0.63 for Net Profit and 0.277 for Return On Equity indicating that the independent variables in the study were able to give information of up to $68.8 \%, 63 \%$ and $27.7 \%$ respectively while the remaining $31.2 \%, 27 \%$ and $72.3 \%$ could not be explained in the study but could be explained using other variables outside the study. All the independent variables were (internet banking, Mobile banking, Automated Teller Machine banking and Debit/Credit banking) found to be positively and significantly related to the Return On Assets while only mobile banking and internet banking were found to be positively and significantly related to Net Profit since their $p$ Values were less 0.05. Automated Teller Machine banking showed a positive relation that was insignificant with the Return on Equity. The study recommends that, electronic banking should be employed by commercial banks through proper management policies since it has shown improved efficiency and financial performance. For further studies, areas of crime technology, quality of banking services, electronic fund transfer and performing loans should be looked at.

Key Words: Electronic Banking, Banking Finance, Mobile Banking, Online Banking, Financial Performance of Commercial Banks

DOI: 10.7176/ijcab.v3iII.24, URN urn:nbn:de:0000ijcab.v3iII.245

\section{Cite this Article:}

Mutisya, M., \& Atheru, G. (2019). Electronic Banking and Financial Performance of Commercial Banks in Kenya. International Journal of Current Aspects, 3(II), 293-304. http://journals.ijcab.org/journals/index.php/ijcab/article/view/24 


\section{INTRODUCTION}

According to the study by Sarreal (2016) on history of internet banking, its evolution began in New York in the year 1981 when banks made home banking available to their customers. Ebanking gained popularity in e-commerce by the year 2000 becoming the main goal of any bank that wished to remain competitive in the world. Most banks in the world by the year 2010 had changed from the traditional ways of doing business to digital ways. Investigation done by Ekekwe (2016) showed that, for the Africa`s banking industry to survive, technology has turned out to be the greatest weapon without which they would not be competitive. It was also found in the study that, for the banks in Africa to maintain their competitive edge, they have to personalize their services in order to retain and attract customers. M-pesa has been proved to be offering services that dislocate the banking architecture of Kenya without even sparing the global banking giants. The future of the banking industry will be for the banks that will be offering high quality services at a low costs.

In their research Ayuma and Munywoki (2012) discovered that, in Kenya information technology has led to increased competition among businesses due to the change in traditional ways of doing business to the digital and electronic way that has led to globalization. Electronic commerce is minimizing time, distance, expenses and space in doing business. The banking industry has been forced to personalize and customize their products and services in order to meet their customer's needs and gain a higher share of the market. In their research Aduda and Kingoo (2012) found that, adoption to electronic banking in Kenya has allowed the banks to create both time and place utility for their customers. Customers can now check their account balances and transfer money without any need to visit the bank premises making electronic banking to become popular. Banks now consider electronic banking as a major contribution to their success and invest more on the automated teller machine that operates twenty four hours, credit cards/debit cards and mobile banking that are more cost saving because they are capital intensive in their operation (Maiyo, 2013). The introduction of electronic banking is driving the economy into a cashless society where consumers will hardly use hard cash in making payments for purchases but instead make electronic credit transfers to the seller's accounts. To retain and attract customers, banks are encouraging the use of electronic banking which was catalyzed by the launching of Safaricom M-Pesa service in March 2007 and the availability of smart phones with internet option that are affordable (Gikonyo,2014).

According to CBK supervision annual report (2015), operating expenses increased from Ksh277, $522 \mathrm{~m}$ in 2014 to Ksh322, 792m in 2015 and return on equity decreased from 10 percent in 2014 to 5 percent in 2015 which was after adoption of e-banking meaning that, most of the bank resources were spent on training the bank employees and advertising within this period leading to high operational costs. There were also increased cases of ICT related fraud which needed to be matched with effective controls. Investigation by Ogare (2013) showed that, despite information technology has been identified to improve banks financial performance, high costs are incurred in its implementation and there is the obstacle of financial insecurity in e-banking due to fraud that is downsizing the number of users which may reduce the bank profit. Several challenges have been associated with e-banking such as: increased costs, insecurity and inadequate skills that may have a negative effect on bank profitability. In the findings by Njuguna (2012), electronic banking is the use of the internet to deliver banking services which includes transfer of funds from one account to another, request for cheque books, account opening, electronic bill payment and enquiry of the bank balance without visiting the bank 
premises. The internet channel is used to reduce operational costs. Its wide geographic coverage and personalization helps to attract and retain customers. In their research Pourkiaei and Ardestani (2014), described electronic banking as when banks do only deliver their services and products through the internet and ATMs without operating in a branch. This helps to reach customers anytime, anyplace, irrespective of the geographic barriers. Electronic banking has been described in different ways by different authors.

According to Isack (2014), electronic banking is when bank clients access bank information and Investigation by Ogare (2013) showed that, despite information technology has been identified to improve banks financial performance, high costs are incurred in its implementation and there is the obstacle of financial insecurity in e-banking due to fraud that is downsizing the number of users which may reduce the bank profit. Several challenges have been associated with e-banking such as: increased costs, insecurity and inadequate skills that may have a negative effect on bank profitability. Bank customers can carry out bank transactions without visiting the bank premises. This may be through telephone, mobile phone, digital television and the computer. According to Ogare (2013), electronic banking is an innovation in the banking industry that involves the use of the internet and telecommunication networks bank services and products. Some of the identified major components of electronic banking include internet banking and electronic funds transfer. In the study done by Gichungu (2015), it was found that financial performance shows the level to which a firm generates its revenue by the use of its assets over a given period of time. The different measures used to measure financial performance should be taken in aggregation. In their study Ngango et al (2015) claimed profitability to be one of the major measures of financial performance. Return on assets (ROA) reflects the level of profitability. Among the other ratios used is return on equity (ROE) which compares the amount of profit earned to the amount invested by shareholders, and the number of ATMs (Asia, 2015).

According to Mwangi (2014), Indicators of profitability were used to asses a bank's financial performance to find out whether electronic banking leads to increased efficiency, effectiveness in terms of cost minimization and time saving. Profitability ratios were used to show management efficiency such as return on assets. This ratio is a measure of net income in relation to total assets that shows how well a firm uses its assets. Investigation done by Maiyo (2013) showed that, the use of electronic banking resulted to reduced costs due to reduced number of bank staff and increased profitability. Banks now operate on self -service basis as opposed to the traditional channels defined on the basis of human assistance, teller or corporate management (Pourkiael and Ardestani, 2014). Electronic payments have resulted to less cheque processing costs, online presentation of bank statements reduced paper and mail distribution costs and less data entry as customers complete most of their transactions online (Njuguna 2012). According to Isack (2014), digital channels are encouraging customers to practice home banking without any need to visit the bank branch. These channels include automated teller machine, mobile banking, credit cards, smart cards and internet banking. Digital banking allows 24 hours service to the bank customers, saves time because the service is offered anytime and anywhere, convenient and environmental friendly because customers do not need to visit the bank physically. Improved customer satisfaction has led to a wider market reach and new market opportunities resulting to increased bank revenue (Njogu, 2014). The Central Bank of Kenya was recognized as the regulatory authority as at $31^{\text {st }}$ December 2015 with fourty four financial institutions. One was a mortgage finance company (MFC) and fourty three commercial banks. Thirty of the fourty three commercial banks were locally owned, the government owns majority of the shares in three of the banks, twenty seven of the local commercial banks are privately 
owned while the other thirteen banks are foreign owned. According to the CBK annual report (2012), local banks accounted for $66.6 \%$ of the Kenya banking sector and $33.4 \%$ for the foreign owned banks. The Central Bank Act, the Banking Act and the Companies Act are some of the guidelines issued by the Central of Kenya that govern the banking industry in Kenya. Banks act as an intermediary between borrowers and savers as they make funds available for investors to borrow. Proper functioning of the financial system in the economy is controlled by the Central Bank of Kenya, through the monetary policy (Mwange, 2013).

\section{STATEMENT OF THE PROBLEM}

According to Kinoti (2015), the dynamic business environment has been associated with changes such as: globalization, personalization and customization of consumer services, changes in technology and competition. Investigation by Rono (2015) showed that, these changes forced commercial banks to innovate in e-banking in order to gain a competitive advantage by: making bank transactions easier, avoiding congestion caused by long queues as bank customers wait to be served, bringing services closer to the customers in order to attract and retain customers in hope of reducing cost of service delivery and improving the financial performance. According to Ngango et al (2015), before the introduction of e-banking, bank customers complained of wastage of allot of time queuing waiting to be served and delay in payment of cheques as representatives of different banks waited in the clearing house for the settlement of their dues. In the study by Njogu (2014) it was found that, bank managers are celebrating after the introduction of e-banking as it results to new market opportunities, increased account sales, wider market reach and increased efficiency. According to the bank supervision annual report (2015), information technology was expected to minimize time, distance, and space and expense thus expanding access to affordable financial services. The number of branches increased by 12 in the year 2015 when compared with year 2012 and the efficiency score increased from 770 to 972 respectively revealing a strong positive relationship. In the study by Njogu (2014) it was found that, electronic banking is allowing banks to change from the traditional channels associated with human assistance to digital channels that operate on self- service basis reducing operational cost and improving efficiency and financial performance.

However, some of the previous researchers give contradicting information on e-baking and the financial performance of commercial banks creating a need for sufficient research to be done on this topic. In their study Aduda and Kingoo (2012) found that, there is a debate among researchers on whether adoption of electronic banking improved bank performance because it required a complementary investment in skills leading to costs that would reduce the bank performance in the short-run.. Commercial bank management therefore needs sound analysis in order to understand all kind of risks to be able to find a balance between costs, risks and the bank financial performance. None of the previous researchers has come up with a clear report on the relationship between e-banking and the financial performance of commercial banks in Kenya. Therefore, this research is to fill the gap by evaluating the influence of electronic banking on the profitability of Kenya Commercial Banks.

\section{RESEARCH OBJECTIVES}

The general objective of the study is to determine the effect of electronic banking on the financial performance of the Kenya commercial banks.

The specific objectives were: 
i. To determine the effect of internet banking on the financial performance of commercial banks in Kenya.

ii. To establish the effect of mobile banking on the financial performance of commercial banks in Kenya.

iii. To establish the influence of ATM banking on the financial performance of commercial banks in Kenya.

iv. To determine the effect of Credit / Debit cards banking on the financial performance of commercial banks in Kenya.

\section{THEORETICAL REVIEW}

Different theories were used in this section to explain electronic banking and the financial performance of commercial banks such as; technological acceptance model, the theory of planned behavior and the consumer internet banking model. The chapter also discusses empirical findings on electronic banking and the financial performance of commercial banks in Kenya showing the knowledge gap by summarizing the literature review.

\subsection{Technology acceptance model}

In their study Davis, Bagozzi and Warshaw (1989), used the technology acceptance model (TAM) to describe how users come to use and accept technology. The decision of users on when and how to use technology is influenced by perceived usefulness (PU) and perceived ease of use (PEOU). Davis et al (1989) explained perceived usefulness as the extent into which one believes there would be improvement of job performance as a result of use of improved technology. According to Ezzi (2014), perceived ease of use is the extent into which one would be free from effort as a result of using a particular system. In their study Davis et al (1989) discovered that, information system that is much easier to use is more likely to influence a positive attitude and the intention to use in order to enhance performance. Perceived usefulness affects attitude towards acceptance of information system which is also affected by the ease of use. Despite ease of use determines acceptance and adoption of information system, it may not explain consumers behavior to adopt internet banking.

\subsection{The Theory of Planned Behavior}

The Theory of Planned Behavior (TPB) was proposed by ajzen(1983) and was used to predict human behavior. The theory suggests that intention to engage in a behavior determines an individual's behavior (Ajzen, 1991). If one intends to use electronic banking the degree to which the person may favor or unfavor the use of e-banking is the attitude in consideration of the outcomes of its use. Subjective norm is another contributing factor that may affect people's intention towards using electronic banking. Subjective norms is an individual's belief regarding important others approval or disapproval of the use of electronic banking. It relates to the persons belief about what important people to the person would think if he or she should use electronic banking. Perceived behavioral control is the perceived likelihood that various events would occur that would encourage or discourage the use of electronic banking this includes past experience as well as expected impediments and obstacles. Teo (2000) employed (TPB) and discovered that benefits of electronic banking have encouraged its increased use in the banking sector. Previous studies on (TPB) suggested that more valuables need to be used to increase predictability. 


\subsection{Consumer Internet Banking Model (CIBM}

Researchers on electronic banking have already discovered the importance of perceived privacy and security. Users of electronic banking fear to provide private information on internet because they do not trust the service providers (Ezzi, 2014). Researchers have already noted consumers concern regarding security, trust and privacy. Experienced users on the security measures employed on the internet have already identified security as the major factor that limits the use of electronic banking.

\subsection{Innovation Diffusion Theory (IDT)}

Rogers (1983) discovered the process of technological diffusion is dictated by uncertainty reduction behavior. The theory is useful to the commercial banks, and the Central Bank since it helps them to encounter electronic banking adoption uncertainties by seeking information from their employees and customers. Taylor (1995) observed that relative advantage determines technological diffusion. Commercial banks can use this theory to know that adoption to electronic banking fits customers practices. This is because they can carry out banking transactions anytime and anywhere without any need to visit the bank premises. Complexity can be encountered by educating the public on how to use electronic banking.

\section{CONCEPTUAL FRAMEWORK}

The conceptual framework is a figure showing the relationship between the dependent variables and the independent variables. 


\section{ATM banking}

- Number of ATMs installed

- Number of active users of ATM banking

- Number of ATM transactions

\section{Internet banking}

- Number of internet banking transactions

- Number of customers using internet banking

- Value of fees and commission from internet banking

\section{Mobile banking}

- Number of active users of mobile banking

- Number of the banks mobile banking transactions

- Capital investment in mobile banking measured in Kenyan shillings

\section{Debit/Credit cards banking}

- Number of Debit/Credit cards issued by banks

- Value of fees and commission from debit and credit cards

- Number of Debit/Credit cards users

Figure 1: Conceptual framework

\section{RESEARCH METHODOLOGY}

A descriptive research design was employed in the study because it will not only show the characteristics of individual banks but of the whole sample. The study was conducted by surveying the registered commercial banks in Kenya. The target population of the study consisted of the 44 commercial banks in Kenya registered with the Central Bank of Kenya as at December 2015. The study comprised of a total number of 44 respondents because in each of the 44 commercial banks, the person in charge of electronic banking will be picked as a respondent. The census sampling procedure was used since there were only 44 commercial banks in Kenya as at $31^{\text {st }}$ December 2015 which were to be easily accessible from their Nairobi offices. The census sampling involved the whole population because the number of banks was small and it 
also eliminated the sampling error. The data that was used in the study was collected from both primary and secondary sources that covered a period of five years from year 2011 to 2015. The Questionnaires were used as a source of primary data and had both closed and open ended questions and were administered through a drop and later pick method. To establish the correlation of total financial performance, regression analysis was adopted using Ordinary Least Square Method where the level of financial performance was taken as the dependent variable and regressed against the chosen independent variables. The Ordinary Least Square selects the regression coefficients that result in the smallest sums of the squared distances between the observed and the predicted values of the dependent variables. The coefficient obtained thus gives the indication of a unit change in the value of the dependent variable as a result of a unit change in any of the independent variables.

\section{DATA ANALYSIS RESULTS}

A correlation analysis was conducted on all the variables under study in order to find out their relationship to each other. Karl Pearson's coefficient of correlation was used in determining the relationships. Financial measures (ROE, ROA and Net Profit) had a positive relationship. All the independent variables had a positive and significant relationship with the ROA. Internet banking and mobile banking showed a positive and significant relationship with the Net Profits. The results also indicated that only one variable which is the ATM Banking transactions had a significantly positive relationship with the ROE. The other independent variables (Mobile transactions, internet transactions and the Debit and Credit card transactions) presented a positive but insignificant relationship with the ROE. A significant and positive relationship was also observed between the Debit/Credit card transactions and the ATM transactions.

In order to test for Multicollinearity, the Variance Inflation Approach was used and it was at a mean of 3.6 which is less than 10 hence indicating that there was no any Multicollinearity in between the variables.

Table 1: Correlation of independent and dependent variables

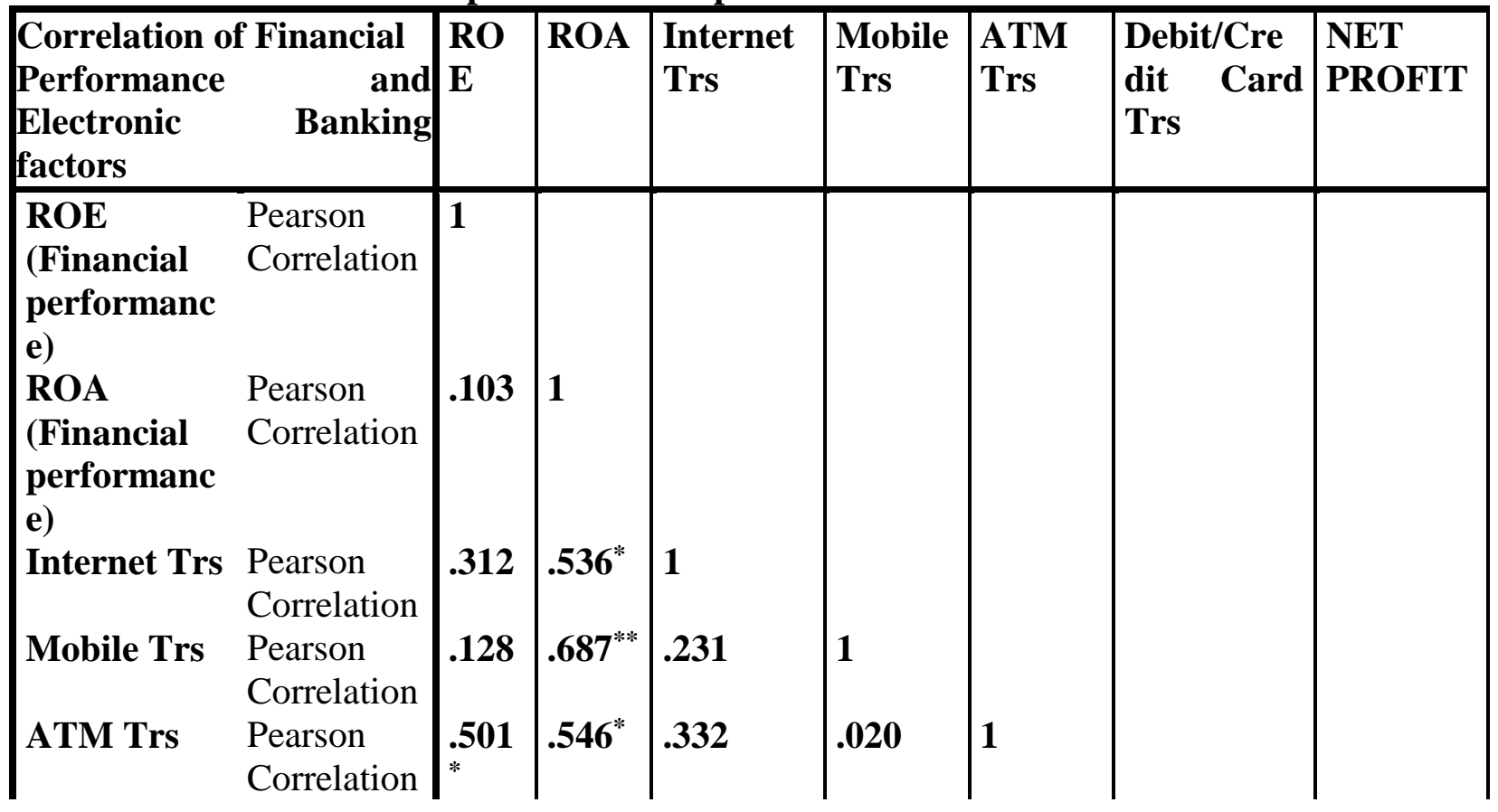


International Journal of Current Aspects, Volume 3, Issue II, 2019, PP 293-304, ISSN 2616-6976

[iJCAB

\begin{tabular}{|c|c|c|c|c|c|c|c|}
\hline $\begin{array}{l}\text { Debit/Credit } \\
\text { Card Trs } \\
\text { NET } \\
\text { PROFIT(Fin } \\
\text { ancial } \\
\text { performance } \\
\text { ) }\end{array}$ & $\begin{array}{l}\text { Pearson } \\
\text { Correlation } \\
\text { Pearson } \\
\text { Correlation }\end{array}$ & $\begin{array}{l}.232 \\
0.45 \\
6\end{array}$ & \begin{tabular}{|l}
$.659^{* *}$ \\
$.511^{*}$
\end{tabular} & .112 & $\begin{array}{l}.014 \\
.773^{* *}\end{array}$ & $\begin{array}{l}.533^{*} \\
.492\end{array}$ & $\begin{array}{l}1 \\
.020\end{array}$ \\
\hline
\end{tabular}

A multivariate regression analysis was conducted in order to determine the relationship and the extent up to which the independent variables (internet transactions, Mobile transactions, ATM transactions and the Debit/ Credit cards transactions) affected the dependent variables.

Table 2: Regression Model summary

\begin{tabular}{clccc}
$\begin{array}{c}\text { FINANCIAL } \\
\text { MEASURES }\end{array}$ & R & R-Squared & Adjusted R Squared & $\begin{array}{c}\text { Std. Error of the } \\
\text { Estimate }\end{array}$ \\
\hline ROA & $0.721^{\mathrm{a}}$ & 0.688 & 0.559 & 0.6841 \\
ROE & $0.326^{\mathrm{a}}$ & 0.277 & 0.167 & 0.9456 \\
NET PROFIT & $0.679^{\mathrm{a}}$ & 0.630 & 0.445 & 0.3982 \\
\hline
\end{tabular}

a. Predictors: (Constant), (Internet transactions, Mobile transactions, ATM transactions and Debit/Credit Card transactions)

Table 2 shows the regression model summary used in the study. A correlation of 0.721 for ROA, 0.326 for ROE and 0.679 for Net Profit was established hence indicating that there was a positive relationship between the independent variables and the dependent. The R Squares of 0.688, 0.277 and 0.630 for the respective measures ROA, ROE and Net Profit indicates that the independent variable in the study were able to give information of up to $68.8 \%, 27.7 \%$ and $63.0 \%$ in relation to the dependent variables while the remaining $31.2 \%, 72.3 \%$ and $37 \%$ could not be explained in the study but could be explained using other variables outside the study.

The Analysis of Variance test was done to test on the significance of the model and it was found to be 0.0004 which is less the p of 0.05. p < 0.05, (0.0004) hence electronic banking has a significant effect on the financial performance of commercial banks in Kenya as shown in table 3 below.

Table 3: Variance Test

\begin{tabular}{cccccc}
\hline & Sum of Squares & df & Mean of Square & F & Sig. \\
\hline Regression & 2759180.02 & 10 & 275918.002 & 5.31 & 0.0004 \\
Residual & 1246852.38 & 24 & 51952.1825 & & \\
Total & 4006032.40 & 34 & 117824.482 & & \\
\hline
\end{tabular}

a. Predictors :( Constant), (Internet transactions, Mobile transactions, ATM transactions and Debit/Credit Card transactions)

b. Dependent Variable: Financial performance measures

The results in table 4 below indicates that internet banking had a positive significant relationship with the ROA which was a measure of financial performance hence a unit increase in internet banking could increase the ROA by 3.850 and this was found to be significant since the p-value was less than $0.05(0.042)$.

Mobile banking had a significantly positive relationship with the ROA since it had a $\mathrm{p}$ Value of 0.002 which is less the standard measure of 0.05 and therefore a unit increase in mobile banking 
could result to an increase in the ROA by 3.482. ATM banking transactions had a $\mathrm{p}$ Value of 0.000 which indicated a significantly positive result to the ROA and hence a unit increase in the ATM banking transactions could result to a 2.742 increase in the ROA. Debit/Credit banking transactions also depicted a positive relationship with the ROA with a $\mathrm{p}$ Value of 0.002 . This implied that a unit increase in Debit/Credit banking transactions could lead to 1.757 increases in the ROA.

Table 4: Regression coefficients (ROA)

\begin{tabular}{|c|c|c|c|c|c|}
\hline Uns & tandard & Coefficients & Standardized Coefficients & $\mathbf{T}$ & Sig \\
\hline & Beta & Std. Error & Beta & & \\
\hline Constant & -4.234 & 2.002 & & -3.561 & 0.042 \\
\hline Internet Trs & 2.750 & 0.056 & 0.687 & 4.432 & 0.002 \\
\hline Mobile Trs & 3.482 & 0.083 & 0.312 & 3.938 & 0.000 \\
\hline ATM Trs & 2.742 & 0.576 & 0.659 & 4.783 & 0.032 \\
\hline Debit/Credit Trs & 1.757 & 2.185 & 0.233 & 5.124 & 0.000 \\
\hline
\end{tabular}

Table 5: Regression coefficients (ROE)

\begin{tabular}{lccccc} 
& \multicolumn{2}{c}{$\begin{array}{c}\text { Unstandardized Coefficients } \\
\text { Beta }\end{array}$} & $\begin{array}{c}\text { Standardized Coefficients } \\
\text { Std. Error }\end{array}$ & $\begin{array}{c}\text { T } \\
\text { Beta }\end{array}$ & Sig \\
\hline Constant & -2.292 & 0.365 & & -1.632 & 0.242 \\
Internet Trs & 1.652 & 0.567 & 0.874 & 1.479 & 0.073 \\
Mobile Trs & 1.462 & 0.874 & 0.282 & 1.747 & 0.364 \\
ATM Trs & 1.879 & 0.239 & 0.678 & 4.783 & 0.004 \\
Debit/Credit Trs & 2.376 & 0.672 & 0.836 & 5.124 & 0.532 \\
\hline
\end{tabular}

Table 6: Regression coefficients (Net Profit)

\begin{tabular}{lccccc} 
& $\begin{array}{c}\text { Unstandardized Coefficients } \\
\text { Beta }\end{array}$ & $\begin{array}{c}\text { Std. Error } \\
\text { Standardized Coefficients } \\
\text { Beta }\end{array}$ & T & Sig \\
\hline Constant & -3.850 & 1.672 & & -2.764 & 0.423 \\
Internet Trs & 1.773 & 0.622 & 0.652 & 3.126 & 0.025 \\
Mobile Trs & 2.772 & 0.267 & 0.445 & 3.051 & 0.016 \\
ATM Trs & 1.164 & 0.678 & 0.876 & 0.785 & 0.525 \\
Debit/Credit Trs & 0.989 & 0.385 & 0.033 & 1.557 & 0.867 \\
\hline
\end{tabular}

\section{CONCLUSION}

From the empirical results it was noted that electronic banking had a positive significant relationship with the ROA and this led to better financial performances of the Kenyan commercial banks. All the variables (internet banking, Mobile banking, ATM banking and Debit/Credit banking) had a positive significant relationship with the ROA hence leading to better financial performance. From the descriptive statistics, it was noted that Mobile banking services were widely used compared to the other services (internet banking, ATM banking and Debit/Credit banking services) while Debit/Credit banking services had the least clients. This is due to the changes in technology levels which is an emerging issue in the banking sector. From the trend analysis, internet banking was the only variable that showed a gradual increase all 
through for the five years. Mobile banking showed a drastic increase in the number of transactions in the year 2014 to 2015 while ATM banking showed a drop.

\section{RECOMMENDATION}

For proper sustainability and growth of the Kenya commercial banks, the banks should enhance the proper usage of the four objectives of the study since it has been proven that they contribute positively to the banks' financial performance. More emphasis should be put at increasing the usage of the Debit/Credit Cards and ATM banking especially when dealing with transactions relating to point of sale more so in super markets, shops and retail stores. Electronic banking should be employed by banks through proper management policies since it has shown that it cuts down the operational and labour costs that are unnecessary to the banks. Paper works are also minimized and the efficiency and profit levels are improved. The Kenyan Government should also support commercial banks in curbing down technological crimes that are on arise since this crimes not only affect the banking industry but they also affect the other sectors hence affecting the Kenyan economy. For further studies, the study recommends that other areas of electronic banking and financial performance should be looked onto. These areas include; quality of electronic banking services, electronic fund transfers and the use of non-performing loans as a measure of the financial performance. The time span should also be expanded from 5 year to 10 years and above for better analysis and interpretation.

\section{REFERENCES}

Aduda, J., \& Kinngoo, N. (2012) .The relationship between e-banking and the financial performance of commercial banks in Kenya.

Ajzen, I. (1991). Theory of planned behavior. Organizational behavior and Human Decision Processes, 50,179-211.

Asia, N.M (2015). Electronic banking and the financial performance of commercial banks in Rwanda. A case of bank of Kingali.

Ayuma, A. M. \& Munywoki, J. M. (2012).E-commerce strategy and performance of commercial banks in Kenya.

Central Bank of Kenya (2012). Supervision annual Report. Nairobi: Author

Central Bank of Kenya (2013). Bank supervision annual report: Kenya. Nairobi: Author

Central Bank of Kenya (2013). Financial Stability Report. Nairobi: Author

Central Bank of Kenya (2015). Supervision annual Report. Nairobi: Author

Central Bank of Kenya (2015-2016). Supervision annual Report. Nairobi: Author

Dang, U. (2011). The camel rating system in banking supervision a case study. Acrada University of applied sciences international business.

Davis, D. F., Baggozi, R. P. \& Warshaw, P. R. (1989).User acceptance of computer technology: a comparison of two theoretical models. 35(8).

Davis, F.D. (1989). Perceived usefulness, perceived ease of use and user acceptance of Information technology. MIS Quarterly, 13(3) 319-340.

Ekekwe, N. (July, 2016). What Africa's banking industry needs to do to servive. International business.

Ezzi, W.S. (2014). A theoretical model for internet banking: Beyond perceived usefulness and ease of use. Archives of business research vol 2, No 2.

Gichungu, Z. N. Oloko, M. A. (2015). Relationship between bank innovations and the financial performance of Commercial banks in Kenya. International Journal of Education and Research.3(5). 
Gikonyo, K. J. (2014, September). Factors influencing the adoption of internet banking in Kenya. IOSR Journal of Business and Management. 16(9), 60-65.

Ho, S. J. \& Mallick, S.K (2006). The impact of banking technology on banking industry: Theory and empirics.

Isack, D. C.(2014). E-banking services - features challenges and benefits.

Kingoo, N. \& Aduda .J. (2012). The relationship between e- banking and the financial performance of commercial banks in Kenya. Journal of finance and investment analysis, 1,(3),2012, 99-118

Kinoti, F. K. (2015). E-banking strategy and performance of commercial banks in Kenya.

Maiyo, J. (2013). The effect of electronic banking on financial performance of commercial banks in Kenya.

Mwange, J .A. (2013). The impact of mobile banking on the financial performance of commercial banks in Kenya.

Mwangi, K.D. (2014).The effect of electronic banking on the financial performance of Commercial banks in Kenya.

Munywoki, J.M. \& Ngigi, E. N. (2011). Challenges of $e$ - banking the commercial banks in Kenya.

Ngango, A., Mbabazzize, M. \& Shukla, J. (2015). E- Banking and performance of commercial banks in Rwanda a case of bank of Kingali. European Journal of Accounting, Auditing, Finance and Research, 3(4). 25-57

Njogu, N. J (2014). Effect of electronic banking on profitability of commercial banks in Kenya.

Njuguna, P. (Septeber, 2012). Internet adoption in Kenya: the case of Nairobi county. International Journal of Business and Social Sciences. 3(18).

Ogare, H.O. (2013). The effect of electronic banking on the financial performance of commercial banks in Kenya. Unpulished MBA project University of Nairobi.

Rono, P. K. (2015). Determinants of electronic banking and operational performance of commercial banks in Kenya.

Sarreal, R. (2016). History of online banking: How internet banking became mainstream.

This is an open-access article published and distributed under the terms and conditions of the $(\mathrm{cc}) \mathrm{EY}$ Creative Commons Attribution 4.0 International License of United States unless otherwise stated. Access, citation and distribution of this article is allowed with full recognition of the authors and the source.

Authors seeking to publish with an International Peer Reviewed Journal should consider www.ijcab.org by writing to the Editor at editor@ijcab.org. List of our Journals are Available at www.ijcab.org/journals 